\title{
НАПРАВЛЕНИЯ РЕАЛИЗАЦИИ ГИБКИХ ТЕХНОЛОГИЙ УПРАВЛЕНИЯ В ПРОМЫШЛЕННОСТИ *
}

\author{
(C) 2021 Шестакова Елена Валерьевна \\ доктор экономических наук, доцент, \\ заведующий кафедрой управления персоналом, сервиса и туризма \\ Оренбургский государственный университет, Россия, Оренбург \\ E-mail: shestakovaev56@gmail.com
}

\section{(C) 2021 Ситжанова Акжан Мурзагуловна}

кандидат экономических наук, доцент кафедры управления персоналом, сервиса и туризма

Оренбургский государственный университет, Россия, Оренбург

E-mail: sithanovak@bk.ru

\section{(c) 2021 Прытков Ринад Михайлович}

старший преподаватель кафедры управления персоналом, сервиса и туризма

Оренбургский государственный университет, Россия, Оренбург

E-mail: r.prytkov@mail.ru

В данной статье рассмотрены основные направления реализации гибких технологий управления на промышленных предприятиях. Представлена классификация промышленных предприятий, выделены ведущие предприятия промышленного сектора экономики Российской Федерации и Оренбургской области. Определены цели внедрения гибких технологий управления, их достижение в промышленности, дан обзор преимуществ использования гибких технологий на промышленных предприятиях. На основе блоков механизма гибкого управления сформированы направления реализации гибких технологий управления на промышленных предприятиях.

Ключевые слова: промышленность, промышленное предприятие, гибкие технологии управления, технология, функции управления, управление в промышленности, реализация гибких технологий.

В условиях изменчивости внешней и внутренней среды, осознания необходимости применения современных подходов к управлению выбор руководителей приходится на различные виды гибких технологий управления, под которыми мы понимает совокупность методов, приемов, способов реализации функций планирования, организации, мотивации, координации, учета, анализа и контроля, как целенаправленного и непрерывного процесса, направленного на осуществление опережающей адаптации предприятия к условиям изменения внешней и внутренней среды.

Существенный вклад в степень разработки направлений реализации гибких технологий управления на предприятиях внесли следующие ученые: А.Д.Алексашкина [1], А.В.Вялова [1], С.А.Никитин [1], В.А.Бошян [2, 3], А. С. Карелина [3], Е.А. Бондарева [3], О.А. Бубнова [4], Ю. В. Клименко [5], А.С.Меликсетян [6], Т.Д.Раева [7], М.Л. Смирнова [8], В.В.Хубулова [9] и другие.

Важно отметить, что до настоящего времени не выявлены направления реализации гибких технологий управления (ГТУ) на промышленных предприятиях (ПП), отсутствует методика оценки и механизм развития ГТУ в промышленности.

Направления реализации гибких технологий управления (ГТУ) на промышленных предприятиях (ПП) заключаются в следующем:

- ориентация на построение организации вокруг процесса вместо создания подразделений на основе функций, выделение основных процессов со специфическими целями на основе сочетания однотипных задач;

- замена жестких бюрократических связей гибкими типами взаимоотношений, дебюрократизация процесса управления, сокращение рутинных операций, формализованных процедур и операций;

- формирование самоорганизуемых, самоуправляемых команд (групп, бригад), объединяющих равноправных высокопрофессиональных специалистов с комплиментарными навыками с

* Исследования выполнены при финансовой поддержке РФФИ в рамках научного проекта № 20-010-00459 21 
целью достижения целей на основе сплоченности, партнерства, солидарной ответственности, групповой самоорганизации;

- формирование гетерархических структур и «плоских» моделей управления, что приводит к минимизации уровней управления, распространению горизонтальных связей, сокращение вертикального администрирования;

- развитие самостоятельности, творческой инициативы, компетентности персонала, обеспечение вовлечение персонала в процесс управления, внедрение эдхократических отношений;

- повышение клиентоориентированности, внедрение технологии маркетинг-менеджмента, заключающейся в ориентации на удовлетворение потребностей различных групп потребителей (поставщики, потребители, посредники, персонала, контактные аудитории, инвесторы);

- внедрение принципов самообучающейся организации, тотальное развитие навыков командного взаимодействия, принятие эффективных коллегиальных решений;

- формирование демократического и знаниевого типа организационной культуры, заключающейся в: решении проблем на основе открытого обсуждения; совместно-творческом типе совместной деятельности; разделении функций и ответственности; согласовании интересов отдельных людей с целями организации; открытых и насыщенных коммуникациях;

- изменение системы стимулирования персонала, ориентация на командные достижения, поощрение развития разнообразных профессиональных навыков [10, 11, 12, 13].

Решение обозначенных проблем, предлагаемых направлений развития промышленных предприятий, связанных с формированием новых инструментов поддержки, технологической модернизацией, снижению административных барьеров, повышением инвестиционной привлекательности, созданием цифровых предприятий, внедрением гибких технологий управления.

Предприятия различных отраслей промышленности имеют свои специфические особенности, которые вытекают из характера производства, применяемой техники и технологии, а также квалификации кадров. В то же время предприятия имеют ряд общих признаков, которые позволяют их классифицировать по ряду направлений (рисунок 1).

Сегодня Российская Федерация - одна из крупнейших держав мира. В зависимости от сво- его потенциала промышленность страны может производить широкий спектр товаров и обслуживать самые важные сферы экономики и жизнедеятельности людей. Несмотря на тяжелый системный кризис 1990-х годов и резкий спад промышленного производства, с начала 2020 года сектор стабильно растет и развивается. Россия входит в четверку лидеров после Китая, США и Индии.

На рисунке 2 отражены ведущие предприятия промышленного сектора экономики Российской Федерации.

Исходя из представленного рисунка, мы видим, что Российская Федерация представлена 16 отраслями, включающими в себя ведущие предприятия промышленного сектора экономики.

При этом наиболее развитыми отраслями российской промышленности являются нефтегазовый сектор, черная и цветная металлургия, общее и транспортное машиностроение, производство пищевых продуктов.

Так, например, машиностроение является ключевой отраслью обрабатывающего производства России. Ведущие машиностроительные предприятия расположены в крупных городах и промышленных зонах Центральной России, Урала, Западной Сибири и Приморья, Поволжья.

В таблице 1 представлены ведущие промышленные предприятия Поволжья, а именно Оренбургской области.

Оренбургская область по объему разведанных запасов и добыче полезных ископаемых входит в ведущую группу регионов Россий Федерации. В области разведано порядка 2500 месторождений 75 видов полезных ископаемых. В числе основных природных ресурсов: нефть, природный газ, конденсат, медноколчеданные комплексные руды, никелевые руды, золото, асбест, каолины, соль каменная.

Индекс промышленного производства на территории Оренбургской области в 2020 году по сравнению с 2019 годом составил 96,0\%. Наибольший удельный вес в ней занимают организации добывающего комплекса. В структуре промышленности региона по объему отгруженных товаров собственного производства в 2020 году добыто полезных ископаемых на сумму 444535,2 млн. рублей, что составляет $22 \%$ от общего количества добытых полезных ископаемых по Приволжскому федеральному округу.

Экономику Оренбургской области, сегодня, в значительной мере определяет металлургическое производство, его доля в общем объеме 


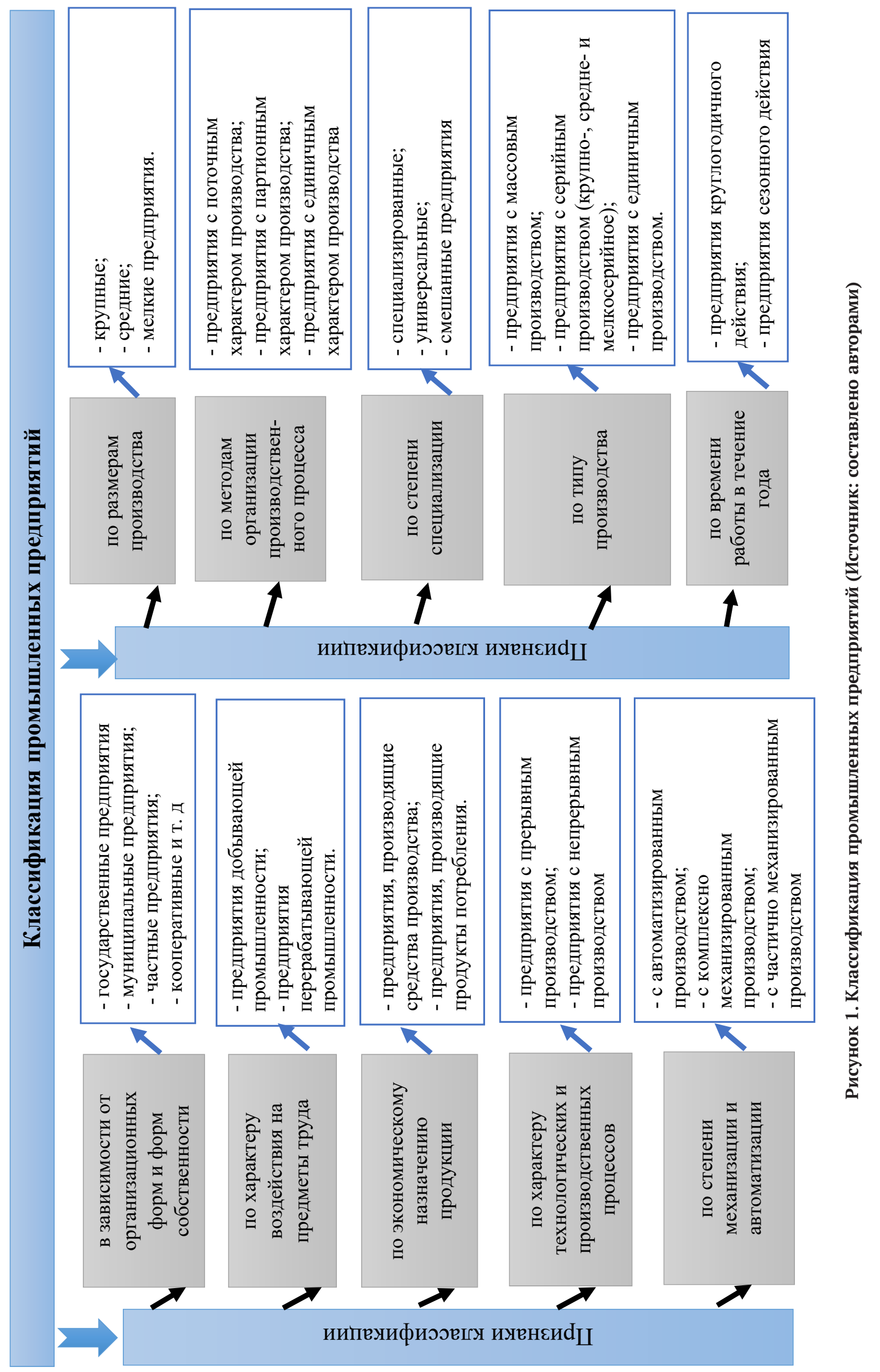




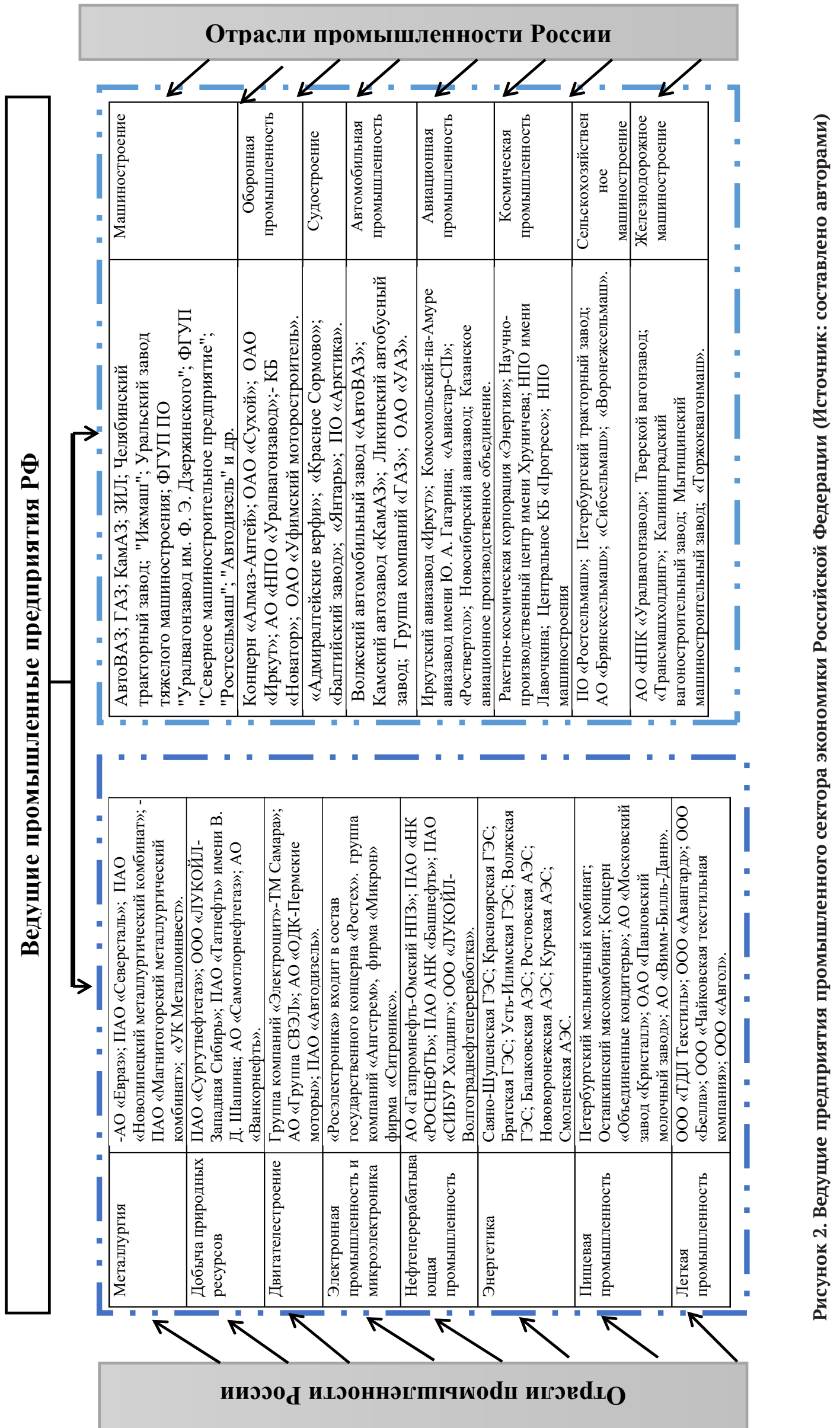


Таблица 1. Ведущие промышленные предприятия Оренбургской области (Источник: составлено авторами)

\begin{tabular}{|l|l|}
\hline \multicolumn{1}{|c|}{ Отрасли промышленности } & \multicolumn{1}{|c|}{ Ведущие промышленные предприятия } \\
\hline Металлургическое произвдство & $\begin{array}{l}\text { АО «Уральская Сталь», ООО «Медногорский медно-серный комбинат», } \\
\text { ООО «ГЗОЦМ», АО «Новотроицкий завод хромовых соединений» }\end{array}$ \\
\hline $\begin{array}{l}\text { Производство машин и оборудо- } \\
\text { вания }\end{array}$ & $\begin{array}{l}\text { АО «ПО «Стрела», АО «Орский машиностроительный завод», АО «Ме- } \\
\text { ханический завод», ООО «Оренбургский радиатор», Оренбургский } \\
\text { локомотивно-ремонтный завод, филиал АО «Желдорреммаш», ОАО } \\
\text { «Медногорский электротехнический завод «Уралэлектро», ОАО «Завод } \\
\text { бурового оборудования», АО «Завод «Инвертор», ОАО «Гидропресс», АО } \\
\text { «Кувандыкский завод кузнечно-прессового оборудования «Долина», } \\
\text { ООО «Джон Дир Русь», филиал в г. Оренбурге }\end{array}$ \\
\hline $\begin{array}{l}\text { Добыча прочих полезных ископа- } \\
\text { емых }\end{array}$ & $\begin{array}{l}\text { ПАО «Гайский ГОК», АО «Оренбургские минералы», ООО «Руссоль», ЗАО } \\
\text { «Ормет» }\end{array}$ \\
\hline $\begin{array}{l}\text { Производство прочей неметалли- } \\
\text { ческой минеральной продукции }\end{array}$ & $\begin{array}{l}\text { ООО «Аккерманн Цемент», ООО «Волма -Оренбург», ООО «Новотроиц- } \\
\text { кий содовый завод», АО «Новотроицкий цементный завод», Орский ще- } \\
\text { бёночный завод филиал ОАО «Первая нерудная компания», АО «Орское } \\
\text { карьероуправление» }\end{array}$ \\
\hline Электроэнергетика & $\begin{array}{l}\text { Филиал АО «Интер РАО - Электрогенерация»- «Ириклинская ГРЭС», } \\
\text { филиал «Оренбургкий» ПАО «Т Плюс», ООО «Авелар Солар Технолод- } \\
\text { жи», АО «Уральская Сталь», ПАО «Гайский ГОК», АО «Солнечный ветер», } \\
\text { ООО «Бугульчанская СЭС» }\end{array}$ \\
\hline $\begin{array}{l}\text { Топливно-энергетический ком- } \\
\text { плекс }\end{array}$ & $\begin{array}{l}\text { АО «Оренбургнефть», ООО «Газпром добыча Оренбург», ООО } \\
\text { «Газпромнефть-Оренбург», ООО «Сладковско-Заречное, ПАО «Преоб- } \\
\text { раженскнефть», ООО «Нефтяная компания «Новый Поток»» }\end{array}$ \\
\hline
\end{tabular}

промышленного производства области составляет $11,4 \%$.

В цветной металлургии предполагается расширение сырьевой базы за счет углубления разработки известных медных и никелевых месторождений и активных геологоразведочных работ. Потенциал увеличения производительности имеет также процесс выплавки цветных металлов и сплавов (меди и ферроникеля), которое будет достигнуто за счет внедрения современных энергоэффективных технологий.

Перспективы повышения конкурентоспособности металлургических предприятий области связаны также с их адаптацией к развитию российского рынка металлов, в первую очередь, металлоемких машиностроительных предприятий, расположенных в регионах Приволжского и Уральского федеральных округов. Одним из возможных механизмов расширения сортамента готовой продукции и наращивания эффективности конечных стадий производства является частичная передача отдельных стадий технологического процесса (раскройка металла, механическая обработка, нанесение полимерного слоя и других) предприятиям малого и среднего бизнеса. Дополнительный импульс к развитию импортозамещающих и малотоннажных производств металлических изделий (как из черных, так и из цветных металлов) может дать в частности, увеличение спроса на медь со стороны производителей энергосберегающего оборудования, что позволит сформировать заказ на определенную продукцию предприятий цветной металлургии области.

Важнейшим направлением развития отрасли является внедрение ресурсосберегающих технологий и снижение негативного воздействия отрасли на окружающую среду.

Металлургический комбинат АО «Уральская Сталь» входит в состав ООО УК «Металлоинвест» - предприятие с полным металлургическим циклом, производит кокс, чугун, сталь, стальной прокат, трубную заготовку.

ООО «Медногорский медно-серный комбинат» металлургическое предприятие, производящее черновую медь и серную кислоту, входит в состав ООО «УГМК-Холдинг». В производственном комплексе комбината действуют медеплавильное производство, брикетная фабрика, цех электролиза меди, цех производства серной кислоты, цех по производству технологического кислорода и ряд вспомогательных производств. На предприятии реализуется проект строительства второй очереди кислородной станции, объем инвестиций составляет 734 млн. рублей.

ООО «ГЗОЦМ» является одним из основных производителей плоского цветного проката (медного, латунного, медно-никелевого и никелевого) в России, а также специализируется на выпуске литейных латуней и бронз. Продукция завода используется на рынке автомобилестроения, строительных материалов, электронной, 
электротехнической, авиационной и оборонной промышленности.

АО «Новотроицкий завод хромовых соединений» производит бихромат натрия, ангидрид хромовый, окиси хрома пигментную и металлургическую, металлический хром, натрий сернокислый, лакокрасочные материалы.

Продукция предприятия применяется в ряде промышленных секторов: машиностроение, судостроение, авиастроение, металлургия, а также текстильная, кожевенная, целлюлознобумажная, стекольная, лакокрасочная, химическая промышленности, производство синтетических моющих средств и т.д.

Производство машин и оборудования осуществляется предприятиями различного профиля, выпускающих оборудование для черной и цветной металлургии, горнорудной промышленности, буровое оборудование для предприятий нефтегазового комплекса и геологоразведки, а также осуществляющих производство продукции для потребностей оборонно-промышленного комплекса, выпуск кузнечно-прессового оборудования, сельхозмашин, комплектующих для транспортных средств и электродвигателей.

В машиностроительный комплекс Оренбургской области входит более 60 крупных и средних предприятий. По состоянию на 01.01.2021 года в отрасли занято более 18 тыс. человек. Доля продукции машиностроения в общем объеме промышленного производства составляет 4,23\%. Проводимая промышленная политика области, направлена на увеличение выпуска предприятиями машиностроения готовой, конкурентоспособной продукции.

$\mathrm{AO}$ «ПО «Стрела» является одним из ведущих предприятий машиностроительной отрасли России и одним из крупнейших многопрофильных предприятий на Урале, входит в структуру АО «Корпорация «Тактическое ракетное вооружение». Предприятие производит продукцию специального назначения, по отдельным заказам выпускает комплектующие и сборочные узлы для предприятий авиационного профиля, детали и узлы для нефтяной и газовой промышленности, для предприятий «РЖД». ПО «Стрела» участвует в российско-индийском военно-техническом сотрудничестве по теме «БраМос» - совместное производство сверхзвуковых крылатых ракет.

АО «Орский машиностроительный завод» специализируется на изготовлении буровых замков, баллонов для сжатых газов и гидроцилиндров. Входит в структуру ООО «ТМК Нефтегазсервис».

АО «Механический завод» специализируется на серийном производстве артиллерийских гильз для различных систем вооружений. Высокое качество выпускаемой продукции традиционно для предприятия. Продукция изготавливается не только по заказу нашей страны, но и для поставок за границы Российской Федерации.

ООО «Оренбургский радиатор» специализируется на выпуске медно-латунных и алюминиевых радиаторов для тракторов, сельскохозяйственных, дорожно-строительных и специальных машин, автопогрузчиков, передвижных электростанций и насосных установок, которые могут эксплуатироваться в различных климатических условиях. Применение прогрессивных технологий, оборудования, экономически обоснованных новых материалов - пластмасс, биметаллов, особо тонких лент и твердых припоев служит главной цели - обеспечению качества и конкурентоспособности выпускаемой продукции.

Оренбургский локомотивно-ремонтный завод, филиал $\mathrm{AO}$ «Желдорреммаш» является крупным предприятием с оснащенной производственной структурой по ремонту маневровых и магистральных тепловозов. Завод является машиностроительным комплексом, включающим литейное, инструментальное, агрегатное, сборочное, электротехническое и испытательное производство, на котором изготавливают более 100 видов деталей для тепловозов и контактной сети, ведут капитальный ремонт маневровых и магистральных локомотивов.

ОАО «Медногорский электротехнический завод «Уралэлектро» специализируется на изготовлении асинхронных электродвигателей и низковольтной коммуникационной аппаратуры.

ОАО «Завод бурового оборудования» производит буровые установки, бурильные трубы, инструмент и запасные части для предприятий геологоразведки на твердые полезные ископаемые.

При финансовом участии Фонда развития промышленности на предприятии проведена комплексная модернизация действующего технологического оборудования с оптимизацией технологических процессов для повышения эффективности общего производственного процесса.

АО «Завод «Инвертор» - современное высокотехнологичное предприятие с высоким 
техническим потенциалом, собственными конструкторскими службами, испытательными лабораториями, обладает многолетним опытом работы в сфере производства электротехнической и электронной продукции промышленного назначения. На заводе создан полный производственный цикл по выпуску силовой преобразовательной техники.

ОАО «Гидропресс» специализируется на производстве широкой номенклатуры серийно поставляемых и специальных гидравлических прессов различного назначения, которые находят применение в различных отраслях промышленности и сельского хозяйства. Завод имеет в своей структуре проектно-конструкторское бюро, оснащенное современным инженерным оборудованием.

АО «Кувандыкский завод кузнечнопрессового оборудования «Долина» выпускает кузнечно-прессовое и металлообрабатывающее оборудование, оборудование для строительства, оборудование для агропромышленного комплекса, товары для коммунального хозяйства.

ООО «Джон Дир Русь», филиал в г. Оренбурге специализируется на производстве сельскохозяйственных почвообрабатывающих агрегатов.

ПАО «ГайскиЙ ГОК» вХодит в состав ООО «УГМК-Холдинг». Основной вид деятельности: добыча, переработка медно-колчеданных руд, выпуск медного, цинкового, пиритного концентратов, серного колчедана, щебня, известняка. Комбинат построен на базе богатейшего месторождения медно-колчеданных руд. Здесь сосредоточено 76\% запасов меди Оренбургской области. В состав основного производства входят: подземный рудник, открытый рудник, обогатительная фабрика.

АО «Оренбургские минералы» специализируется на добыче и обогащении хризотилосодержащих руд Киембаевского месторождения.

ООО «Руссоль» специализируется на добыче и переработке каменной соли. Добыча ведется подземным способом, выданная на поверхность соль поступает на солефабрику, которая включает в себя солемельницу и цех упаковки готовой продукции.

ЗАО «Ормет» осуществляет добычу и обогащение руды, а также выпуск медного и цинкового концентратов. Входит в состав $3 \mathrm{AO}$ «Русская медная компания».

ООО «Аккерманн Цемент» является одним из крупнейших производителей цемента в России, специализируется на производстве цемен- та, известняка, шлакового щебня.

ООО «Волма - Оренбург» осуществляет добычу и дробление гипсового камня, производит строительные материалы на основе гипсового вяжущего сырья Дубенского рудника. Производство рассчитано на полный технологический цикл - от добычи сырья до отгрузки готовой продукции потребителям.

ООО «Новотроицкий содовый завод» основным видом деятельности является производство неорганических химических веществ, сухих строительных смесей и извести.

АО «Новотроицкий цементный завод» специализируется на выпуске цемента строительного, портландцемента.

Орский щебёночный завод является филиалом ОАО «Первая нерудная компания», создан на базе имущества ОАО «Российские железные дороги», осуществляет добычу декоративного и строительного камня, известняка, гипса, мела и сланцев.

АО «Орское карьероуправление» специализированное предприятие по добыче и переработке габбро-диабазов Круторожинского месторождения на щебень и строительный песок.

Энергосистема Оренбургской области граничит с энергосистемами субъектов Российской Федерации: Самарской области, Республики Татарстан, Республики Башкортостан, Челябинской области и энергосистемой сопредельного государства - Республики Казахстана. Оренбургская энергосистема входит в состав Объединенной энергосистемы Урала.

На территории Оренбургской области осуществляют деятельность 55 организаций, оказывающих услуги по передаче электрической энергии.

Наиболее крупными из них являются:

- филиал ПАО «ФСК ЕЭС» - «Оренбургское предприятие МЭС»,

- филиал ПАО «МРСК Волги» - «Оренбургэнерго»,

- АО «Оренбургнефть»,

- Южно-Уральский филиал ООО «Газпром энерго»,

- Южно-Уральская железная дорога - филиал ОАО «РЖД»,

- Куйбышевская железная дорога - филиал

ОАО «РЖД»,

- ГУП «Оренбургкоммунэлектросеть» (ГУП «ОКЭС»),

- АО «Оборонэнерго»,

- 000 «Электросетевая компания». 
Топливно-энергетический комплекс Оренбургской области является важной составной частью промышленности области и занимает $42 \%$ в объёме промышленного производства Оренбуржья.

В экономике региона топливно-энергетический комплекс играет роль базовой инфраструктуры, основы формирования доходов бюджетной системы и крупнейшего заказчика для других отраслей.

Наиболее крупные нефтегазодобывающие предприятия входят в состав «Роснефти», «Газпрома» и Нефтяной компании «РуссНефть».

К ним относятся: крупнейшее нефтедобывающее предприятие в Оренбуржье - «Оренбургнефть»; ключевое предприятие «Газпрома» по добыче природного газа и газового конденсата в Оренбургской области - «Газпром добыча Оренбург»; Нефтяная компания «Новый Поток», которая осуществляет подготовку к вводу в разработку месторождений на территории национального парка в Бузулукском районе; динамично развивающиеся нефтяные компании - «Газпромнефть Оренбург», «СладковскоЗаречное», «Преображенскнефть» $[14,15]$.

Таким образом, перечисленные предприятия Оренбургской области оказывают значительное влияние на экономику региона, являются круп- нейшими налогоплательщиками и активными участниками социальной жизни региона.

В современных условиях на промышленных предприятиях России и ее регионов необходимо применять гибкие методологии управления координационными схемами направленные на минимизацию рисков. Службу любого управляемого отделения промышленного предприятия, возможно осуществить равно как серию кратких циклов, которые быстро адаптируются под воздействие внешних и внутренних факторов.

Любой такой цикл представляет собой самостоятельный проект который управляется с использованием гибких технологий в области: планирования, кодирования, проектирования, программирования, тестирования, документирования и старта производства нового товара. При этом на применимость гибких технологий влияют такие факторы, как уровень культуры компании, состав и структура коллектива и сформировавшиеся коммуникации.

На рисунке 3 отражены цели внедрения гибких технологий управления на промышленных предприятиях и их достижение.

Исходя из представленного рисунка можно отметить, что наиболее приоритетными целями внедрения гибких технологий управления на промышленных предприятиях являются следу-
Облегчить поддержку продуктов

Снизить проектные затраты

Лучше управлять распределенными командами

Снизить проектные риски

Улучшить инженерную культуру

Повысить предсказуемость поставок

Повысить мотивацию команд

Улучшить прозрачность ведения проектов

Увеличить производительность

Обеспечить согласованную работу бизнеса

Повысить качество продуктов

Лучше управлять меняющимися приоритетами

Ускорить поставки / выход продуктов на рынок

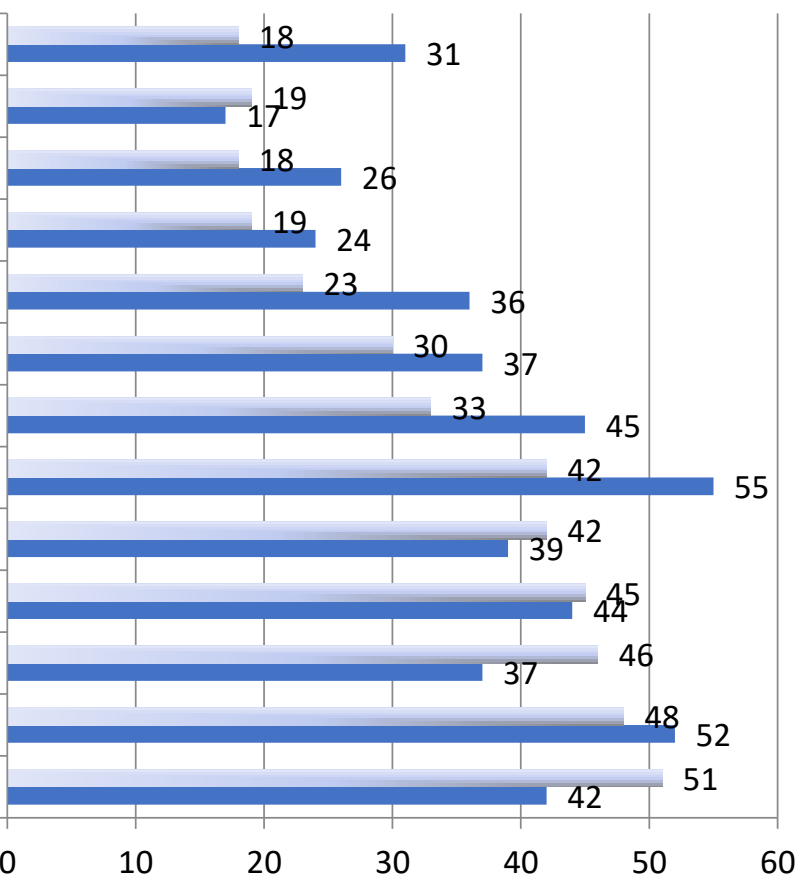

Цель Ваметное улучшение

Рисунок 3. Цели внедрения гибких технологий управления и их достижение на промышленных предприятиях, \% 
ющие: ускорение поставок (выход) продуктов на рынок, лучшее управление меняющимися приоритетами, повышение качества производимых продуктов. При этом заметные улучшения касаются улучшения прозрачности ведения бизнеса, лучшего управления меняющимися приоритетами, а также пошения мотивации команд промышленного предприятия.

Преимущества использования ГТУ на ПП отражены на рисунке 4.

Главными условиями, которые гарантируют результат введения гибких технологий, считаются:

- уровень культуры, сформировавшийся на предприятии, должен содействовать переговорам, а также принятию оптимальных решений;

- руководители предприятий должны доверять персоналу;

- квалифицированный (однако, допустимо, не многочисленный) штат;

- технический персонал имеет право принимать решения, оказывающие влияние на ход проектов;

- условия труда должны способствовать ин- тенсивному общению членов команды [10].

В таблице 2 описаны направления реализации ГТУ на промышленных предприятиях в современных условиях.

Направления реализации ГТУ на ПП сформированы на основе шести блоков механизма гибкого управления: маркетингового, организационного, кадрового, экономического, производственного, информационного. Каждый блок механизма гибкого управления включает комплекс мероприятий необходимых для формирования и развития гибких технологий управления на промышленном предприятии. Реализуя данные направления в рамках каждого блока, промышленное предприятие сможет применять следующе гибкие технологии управления: методология «Lean» («бережливое производство»), «Канбан», «Шесть сигм», «Dynamic Software Development Method (DSDM)», «Quick Response Manufacturing (QRM)», методология «Scrum», «Коучинг», «Trello», «Crystal Clear» и другие $[16,17]$. Использование гибких технологий при управлении промышленными предприятиями позволяет максимально быстро реагировать на

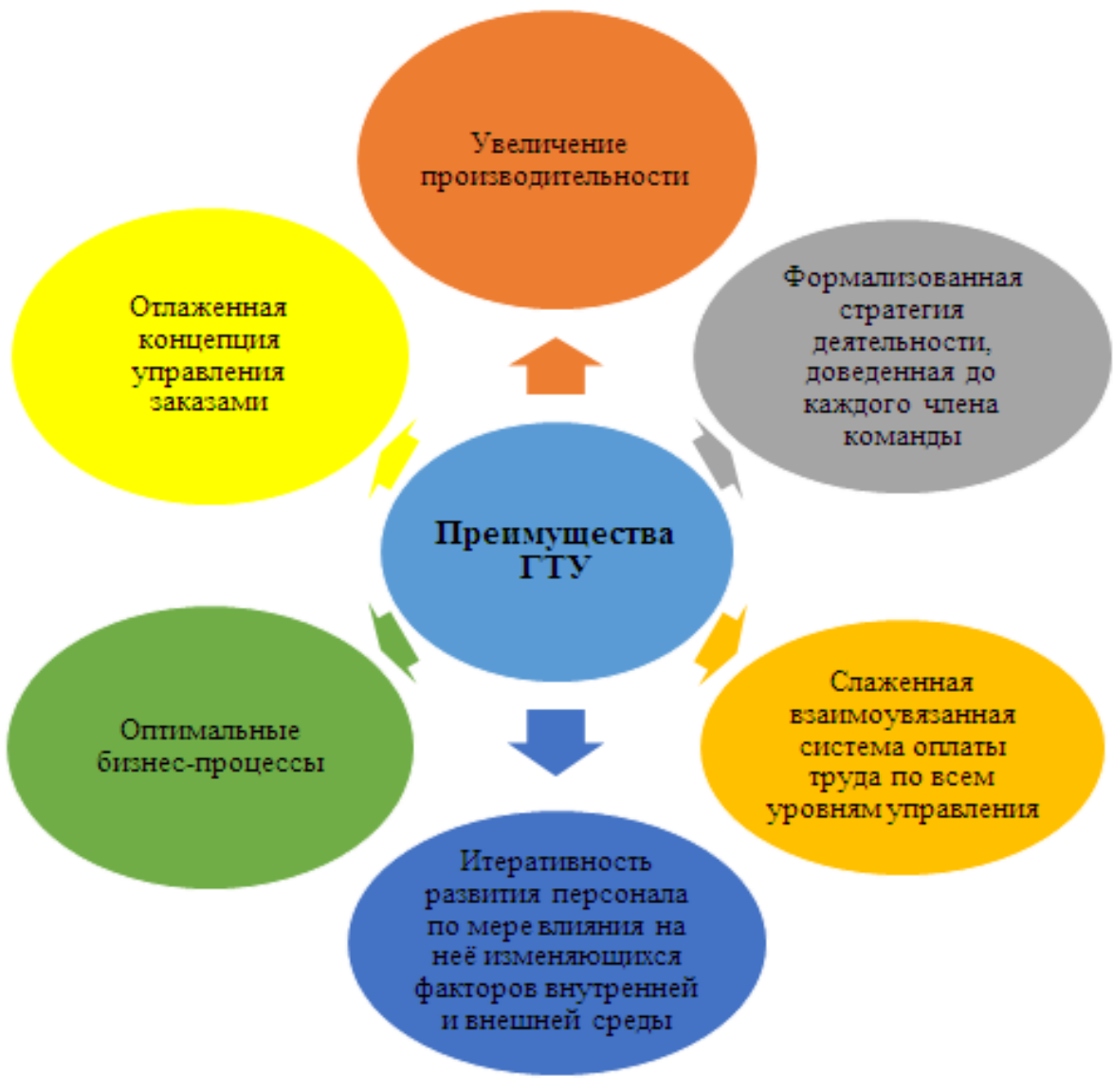

Рисунок 4. Обзор преимуществ использования гибких технологий на промышленных предприятиях (Источник: составлено авторами) 
возрастающую сложность и непредсказуемость проектов, и предполагают максимальную гибкость всех процессов разработки при наличии необходимого уровня контроля над ходом проекта.
Таким образом, мы предложили ряд направлений для реализации гибких технологий управления в отраслях промышленности, которые должны основываться на системном подходе с учетом факторов внешней и внутренней среды.

Таблица 2. Направления реализации ГТУ на промышленных предприятиях (Источник: составлено авторами)

\begin{tabular}{|c|c|c|}
\hline $\begin{array}{l}\text { Блок меха- } \\
\text { низма ГТу }\end{array}$ & \begin{tabular}{|c} 
Гибкие технологии управ- \\
ления ПП
\end{tabular} & Направления реализации ГТУ \\
\hline \multirow{2}{*}{ 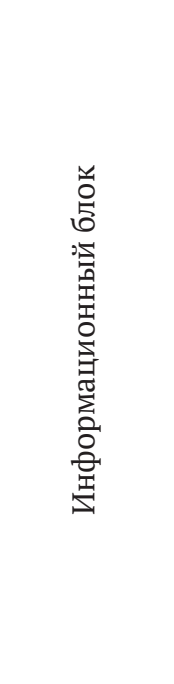 } & \multirow[t]{2}{*}{$\begin{array}{l}\text { - Методология Lean («бе- } \\
\text { режливое производство»). } \\
\text { - Канбан. } \\
\text { - Шесть сигм. } \\
\text { - Dynamic Software } \\
\text { Development Method } \\
\text { (DSDM). } \\
\text { - Quick Response } \\
\text { Manufacturing (QRM). } \\
\text { - Meтодология Scrum. } \\
\text { - Коучинг. } \\
\text { - Trello. } \\
\text { - Crystal Clear и др. }\end{array}$} & $\begin{array}{l}\text { Осуществлять на предприятии учет временного фактора разра- } \\
\text { ботки продукта (под временем разработки продукта понимается } \\
\text { объем требований, реализованных за определенный промежуток } \\
\text { времени). } \\
\text { Периодически осуществлять контроль скорости разработки про- } \\
\text { дукта, проводить сравнительный анализ плановых и фактических } \\
\text { показателей. } \\
\text { Взять проект на особый контроль и сформировать систему отсле- } \\
\text { живания процесса по работе над проектом. } \\
\text { Учитывать при планировании запас времени и прошлый опыт. } \\
\text { Минимизировать воздействие отвлекающих факторов. }\end{array}$ \\
\hline & & $\begin{array}{l}\text { Учитывать возможную разницу стоимости продукции произведен- } \\
\text { ной ПП в связи с изменением цен на сырье предприятий партне- } \\
\text { ров. } \\
\text { Провести проверку траты средств и причин выбора задач с мини- } \\
\text { мальной ценностью. } \\
\text { Учитывать мнение заказчика при отборе задач, контролировать } \\
\text { направления расходования бюджета проекта. } \\
\text { Зафиксировать факторы, обеспечивающие высокую ценность. }\end{array}$ \\
\hline \multirow[t]{2}{*}{ 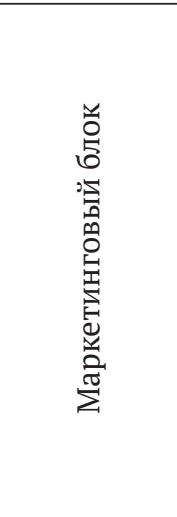 } & \multirow{2}{*}{$\begin{array}{l}\text { - Методология Lean («бе- } \\
\text { режливое производство»). } \\
\text { - Канбан. } \\
\text { - Шесть сигм. } \\
\text { - Dynamic Software } \\
\text { Development Method } \\
\text { (DSDM). } \\
\text { - Quick Response } \\
\text { Manufacturing (QRM). } \\
\text { - Meтодология Scrum. } \\
\text { - Коучинг. } \\
\text { - Trello. } \\
\text { - Crystal Clear и др. }\end{array}$} & $\begin{array}{l}\text { Исследовать рынок, проводить опросы клиентов ПП на предмет } \\
\text { удовлетворенности потребности. } \\
\text { Предоставить возможность заказчику оценить удовлетворенность } \\
\text { по трем направлениям: удовлетворенность результатами, взаимо- } \\
\text { действие команды, профессионализм команды. } \\
\text { Передать проект другой команде (сменить отдельных ее членов). } \\
\text { Оптимизировать систему взаимодействия заказчика, провести } \\
\text { мероприятия по удержанию заказчика. } \\
\text { Зафиксировать факторы, обеспечивающие высокую удовлетворен- } \\
\text { ность клиента. }\end{array}$ \\
\hline & & $\begin{array}{l}\text { Увеличивать долю рынка наращивая объемы продаж. } \\
\text { Учитывать товарные запасы промышленного предприятия, увели- } \\
\text { чивая количество их оборота за счет осуществления маркетинго- } \\
\text { вых мероприятий. }\end{array}$ \\
\hline \multirow{3}{*}{ 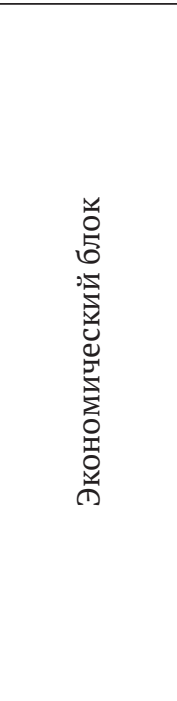 } & \multirow{3}{*}{$\begin{array}{l}\text { - Методология Lean («бе- } \\
\text { режливое производство»). } \\
\text { - Канбан. } \\
\text { - Шесть сигм. } \\
\text { - Dynamic Software } \\
\text { Development Method } \\
\text { (DSDM). } \\
\text { - Quick Response } \\
\text { Manufacturing (QRM). } \\
\text { - Методология Scrum. } \\
\text { - Коучинг. } \\
\text { - Trello. } \\
\text { - Crystal Clear и др. }\end{array}$} & $\begin{array}{l}\text { Вести нормативы расходов на одну деловую встречу. } \\
\text { Оптимизировать количество запланированных мероприятий, } \\
\text { пересмотрев план-график рабочих встреч административно- } \\
\text { управленческого персонала. } \\
\text { Пересмотреть бюджет представительских расходов на необходи- } \\
\text { мость и целесообразность использования. } \\
\text { Снизить количество звеньев управления за счет исчисления, на } \\
\text { основании экспериментальных данных. }\end{array}$ \\
\hline & & $\begin{array}{l}\text { Рассчитать отклонения планового бюджета от фактического. } \\
\text { Осуществлять согласование фактического бюджета со всеми участ- } \\
\text { никами проекта. } \\
\text { Учитывать количество расходов на итерацию. }\end{array}$ \\
\hline & & $\begin{array}{l}\text { Регулярно проводить мониторинг платежеспособности, финан- } \\
\text { совой устойчивости и рентабельности проектов. Для этого необ- } \\
\text { ходимо: учитывать рентабельность деятельности (оценку рента- } \\
\text { бельности проекта); величину чистых активов (оценку финансовой } \\
\text { устойчивости проекта); соотношение заемных и собственных } \\
\text { средств (оценку финансовой устойчивости проекта); коэффициент } \\
\text { покрытия долга (оценку платежеспособности проекта). }\end{array}$ \\
\hline
\end{tabular}




\begin{tabular}{|c|c|c|}
\hline \multirow{5}{*}{ 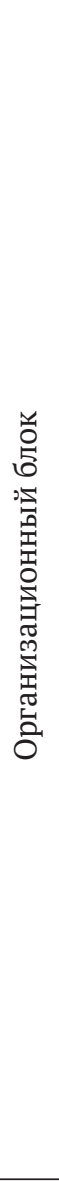 } & \multirow{5}{*}{$\begin{array}{l}\text { - Методология Lean («бе- } \\
\text { режливое производство»). } \\
\text { - Канбан. } \\
\text { - Шесть сигм. } \\
\text { - Dynamic Software } \\
\text { Development Method } \\
\text { (DSDM). } \\
\text { - Quick Response } \\
\text { Manufacturing (QRM). } \\
\text { - Методология Scrum. } \\
\text { - Kоучинг. } \\
\text { - Trello. } \\
\text { - Crystal Clear и др. }\end{array}$} & $\begin{array}{l}\text { Снижать количество дефектов, выявленных во время тестирования } \\
\text { и после поставки результатов заказчикам. } \\
\text { Производить регулярное тестирование продукции и оценивать } \\
\text { качество разработок. Качество результатов итерации необходимо } \\
\text { суммировать. }\end{array}$ \\
\hline & & $\begin{array}{l}\text { Производить учет издержек связанных с нормирование труда руко- } \\
\text { водителей и специалистов ПП. } \\
\text { Эффективность трудовой деятельности руководителя следует под- } \\
\text { вергать оценке не по количеству составленных отчетов и выданных } \\
\text { распоряжений, а по результативности и прогрессивности прини- } \\
\text { маемых управленческих решений - по их влиянию на результаты } \\
\text { деятельности работников, непосредственно занятых производ- } \\
\text { ством продукции. }\end{array}$ \\
\hline & & $\begin{array}{l}\text { Учитывать количество производственного времени, затрачиваемо- } \\
\text { го в каждом подразделении ПП. } \\
\text { Учитывать рациональность организации рабочего места, обяза- } \\
\text { тельность во взаимоотношениях, четкость постановки проблем и } \\
\text { путей их решения. } \\
\text { Осуществлять оценку эффективности труда участников проекта. } \\
\text { Применять приемы эффективного использования программного } \\
\text { обеспечения. } \\
\text { Устранять конфликтные ситуации при разработке проекта. }\end{array}$ \\
\hline & & $\begin{array}{l}\text { Учитывать простои по работе над проектом. } \\
\text { Исследовать причины и условия возникновения рисков при работе } \\
\text { над проектом. } \\
\text { Оценивать общий фонд работ по выполнению проекта. } \\
\text { Установить число подразделений, задействованных в проекте. }\end{array}$ \\
\hline & & $\begin{array}{l}\text { Оценивать уровень квалификации персонала задействованного в } \\
\text { проекте. } \\
\text { Выявить оптимальную численность команды проекта, соотнеся ее с } \\
\text { фактической численностью. } \\
\text { Определить фактический состав руководителей проектов. }\end{array}$ \\
\hline \multirow{4}{*}{ 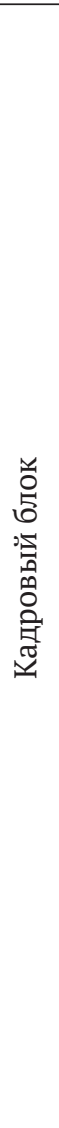 } & \multirow{4}{*}{$\begin{array}{l}\text { - Методология Lean («бе- } \\
\text { режливое производство»). } \\
\text { - Канбан. } \\
\text { - Шесть сигм. } \\
\text { - Dуnamic Software } \\
\text { Development Method } \\
\text { (DSDM). } \\
\text { - Quick Response } \\
\text { Manufacturing (QRM). } \\
\text { - Mетодология Scrum. } \\
\text { - Kоучинг. } \\
\text { - Trello. } \\
\text { - Crystal Clear и др. }\end{array}$} & $\begin{array}{l}\text { Выявить дублирующие и не закрепленные функции участников } \\
\text { проекта. } \\
\text { Перераспределить функции между участниками проектов. } \\
\text { Соотнести количество работ, проводимых в аппарате управления } \\
\text { фактически и по установленным положениям. }\end{array}$ \\
\hline & & $\begin{array}{l}\text { Вывить степень надежности (ответственности), компетентности } \\
\text { участников проекта. } \\
\text { Оценить ценный конечный продукт (ЦКП) каждого участника } \\
\text { системы управления. } \\
\text { Выявить количество удовлетворительных и не удовлетворительных } \\
\text { решений заданным требованиям. }\end{array}$ \\
\hline & & $\begin{array}{l}\text { Выявить готовность персонала к самообучению, инновациям, } \\
\text { степень самомотивированности, лидерского потенциала, демокра- } \\
\text { тичность команды проекта, возможность для самореализации и } \\
\text { саморазвития. } \\
\text { Определить количество важных предложений, ценностей, правил } \\
\text { разделяемых участниками проекта. } \\
\text { Сформировать представление о корпоративной культуре, конкре- } \\
\text { тизировать ее элементы. } \\
\text { Идентифицировать количество участников, разделяющих принци- } \\
\text { пы корпоративной культуры ПП. } \\
\text { Обосновать варианты поведения участников проекта в различных } \\
\text { ситуациях. } \\
\text { Определить базовый уровень корпоративной культуры, который } \\
\text { состоит из внешнего, внутреннего и скрытого уровня. }\end{array}$ \\
\hline & & $\begin{array}{l}\text { Определить эффективность использования материальных, тру- } \\
\text { довых и денежных ресурсов во время жизненного цикла проекта } \\
\text { (ЖЦП). } \\
\text { Оптимизировать затраты управленческого персонала на реализа- } \\
\text { цию их функций. } \\
\text { Оценить качество управления активами ПП. }\end{array}$ \\
\hline
\end{tabular}




\begin{tabular}{|c|c|c|}
\hline \multirow{3}{*}{ 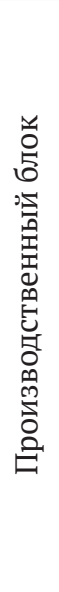 } & \multirow{3}{*}{$\begin{array}{l}\text { - Методология Lean («бе- } \\
\text { режливое производство»). } \\
\text { - Канбан. } \\
\text { - Шесть сигм. } \\
\text { - Dynamic Software } \\
\text { Development Method } \\
\text { (DSDM). } \\
\text { - Quick Response } \\
\text { Manufacturing (QRM). } \\
\text { - Mетодология Scrum. } \\
\text { - Kоучинг. } \\
\text { - Trello. } \\
\text { - Crystal Clear и др. }\end{array}$} & $\begin{array}{l}\text { Определить время, затраченное на приведение системы в рабочее } \\
\text { состояние за определенный отрезок эксплуатации оборудования. } \\
\text { Составить график технического обслуживания и планового ремон- } \\
\text { та оборудования ПП. }\end{array}$ \\
\hline & & $\begin{array}{l}\text { Выйти на показатели стабильности производства ПП. } \\
\text { Сформировать гарантированные заказы ПП. } \\
\text { Определить эффективность использования основных и оборотных } \\
\text { фондов ПП. } \\
\text { Рационализировать систему организации производства и труда } \\
\text { ПП. } \\
\text { Оптимизировать систему управления производством с учетом ГТУ. }\end{array}$ \\
\hline & & $\begin{array}{l}\text { Отслеживать достижения науки и техники (новых технологий). } \\
\text { Совершенствовать организацию производства ПП. } \\
\text { Поддерживать уровень информатизации процессов управления. } \\
\text { Развивать кадровый потенциал и инновационность кадров на всех } \\
\text { уровнях управления ПП. }\end{array}$ \\
\hline
\end{tabular}

\section{Исследования выполнены при финансовой поддержке РФФИ в рамках научного проекта № 20-010-00459\21}

\section{Библиографический список}

1. Алексашкина, А. Д. Анализ гибких технологий управления А. Д. Алексашкина, А. В. Вялова, С. А. Никитин // в сборнике: Приоритетные и перспективные направления научно-технического развития Российской Федерации / материалы III Всероссийской научно-практической конференции.- Москва, 2020.- C. 4-6.

2. Бошян, В.А. Внедрение гибких технологий управления: выгоды и проблемы / В.А.Бошян // в сборнике: Приоритетные и перспективные направления научно-технического развития Российской Федерации / материалы III Всероссийской научно-практической конференции.- Москва, 2020.- С. 11-13.

3. Бошян, В. А. Возможности применения гибких технологий управления проектами в различных сферах бизнеса / В.А.Бошян, А.С. Карелина, Е.А.Бондарева // в сборнике: Горизонты развития проектного управления: теория и практика. Материалы Международной научно-практической конференции. - 2020.- С. 5-7.

4. Бубнова, О.А.Внедрение гибких технологий управления в ПАО «Сбербанк» / О.А. Бубнова // в сборнике: Горизонты развития проектного управления: теория и практика. Материалы Международной научнопрактической конференции.-2020.- С. 7-10.

5. Клименко, Ю.В. О необходимости разработки на предприятиях морского транспорта технологии управления на основе гибких целей / Ю. В. Клименко // Вестник ИНЖЭКОНа. Серия: Экономика. - 2013. - № 5 (64). С. 164-167.

6. Меликсетян, А. С. Особенности внедрения гибких технологий управления инновационными проектами на промышленном предприятии / А. С. Меликсетян // в сборнике: Шаг в будущее: искусственный интеллект и цифровая экономика. Революция в управлении: новая цифровая экономика или новый мир машин. Материалы II Международного научного форума. - 2018. - С. 77-80.

7. Раева, Т.Д.Анализ применения гибких технологий в управлении проектами в России и за рубежом / Т.Д.Раева // сборник научных трудов вузов России «Проблемы экономики, финансов и управления производством».-2018. - № 43.- С. 53-58.

8. Смирнова, М.Л. Возможности и угрозы внедрения гибких технологий управления проектами / М.Л. Смирнова // сборник научных трудов: Образовательная система: структурные преобразования и перспективные направления развития научной мысли.-Казань, 2019.- С. 323-325.

9. Хубулова, В.В.Новая парадигма управления организационной культурой: гибкие технологии / В. В. Хубулова // в сборнике: Преподаватель года 2020. Сборник статей Международного научно-методического конкурса. В 2-х частях.-2020.- С. 30-36.

10. Шестакова, E.В.Развитие гибких организационных структур управления промышленными предприятиями [Электронный ресурс] / Е. В.Шестакова, А. М. Ситжанова, Р.М.Прытков // Экономика и предпринимательство,2020. - № 8 (121)._- С. 972-976. 
11. Шестакова, Е.В.Появление и необходимость применения гибких технологий управления в деятельности современных предприятий в условиях изменения внешней среды [Электронный ресурс] / Е. В.Шестакова, А. М. Ситжанова, Р. М.Прытков // Современные тенденции и технологии развития потенциала регионов: сб. ст. Первой Нац. науч.-практ. конф., 24 апр. 2020 г., Санкт-Петербург.- Электрон. дан.-Санкт-Петербург: Санкт-Петерб. ун-т технологий упр. и экономики,2020.- Ч. 1.- С. 46-52.

12. Шестакова, E.B.Scrum-команда, реализующая гибкие технологии управления на промышленных предприятиях / Е. В.Шестакова, А. М. Ситжанова, Р. М.Прытков // в сборнике: Современные тенденции и технологии развития потенциала регионов. Сборник статей Национальной научно-практической конференции. Санкт-Петербург, 2021.- С. 95-102.

13. Шестакова, Е.В.Перспективные направления самоорганизации производственно-экономических систем в промышленности строительных материалов [Электронный ресурс] / Е. В.Шестакова // Экономика и предпринимательство,2017.- № 2-1 (79-1).- С. 692-697.

14. Официальный портал Правительства Оренбургской области.- Режим доступа: https://orenburg-gov.ru/.09.06.2021.

15. Прытков, Р.М.Особенности производственной специализации Оренбургской области [Электронный ресурс] / Прытков Р. М. // Вестник Оренбургского государственного университета,2014. - № 8.- С. $127-132$.

16. Шестакова, E.В. Гибкие технологии управления: инновационный дискурс классификационных признаков [Электронный ресурс] / Е. В.Шестакова, А. М. Ситжанова, Р. М.Прытков // Экономические науки,2020.№ $188 .-$ C. $99-106$.

17. Шестакова, Е.В. Гибкие технологии управления: сущность, функции, признаки гибкости, разновидности agile-методологий [Электронный ресурс] / Е. В.Шестакова, А. М. Ситжанова, Р. М. Прытков // Менеджмент в России и за рубежом,2020.- № 5.- С. 84-90. 